\title{
BRITISH COLONIAL ERA'S RELIGIOUS BUILT HERITAGE IN YORUBALAND, NIGERIA: KEY CONSERVATION PROBLEMATICS AND THE STATE OF KNOW-HOW
}

\author{
REYHAN SABRI ${ }^{1 *}$ AND OLUSEYI A. OLAGOKE ${ }^{2}$ \\ ${ }^{1}$ Assistant Professor, Department of Architectural Engineering, College of Engineering \\ University of Sharjah \\ University City, Sharjah, UAE \\ e-mail: rsabri@sharjah.ac.ae, www.sharjah.ac.ae $(*$ corresponding author $)$ \\ ${ }^{2}$ Independent Researcher \\ Osogbo, Osun State, Nigeria \\ email: oluseyiolagoke@gmail.com
}

Keywords: Religious Built Heritage, Conservation Problematics, Spatial Requirements, Modification of Original Fabric, Adaptive Reuse

\begin{abstract}
Colonial-era buildings' conservation is now viewed in a more positive light as part of the urban fabric, however the conservation state of colonial-era built heritage has received scant research attention. There are major challenges especially for the preservation of religious buildings erected in the former European colonial territories in the nonWestern world. This paper is the outcome of ongoing fieldwork-based research, which aims to identify and locate the mosque and church structures built during the British colonial era in Yorubaland (South Western Nigeria) and investigates their conservation state. This research adopts a mixed methods approach, employing physical observations and semistructured interviews with heritage practitioners. The analysis of the fieldwork data initiates a discussion on the challenges and threats that result from the spatial requirements of a growing number of congregations which have lead to physical interventions on the original fabric, ranging from minor to major modifications and demolitions. The deficiencies in institutional conservation know-how in addressing the emerging spatial requirements in theoretically and technically appropriate ways are revealed.
\end{abstract}

\section{INTRODUCTION}

Protection of the architectural legacies of the modern European colonial era is a multifaceted issue, underpinned by various socio-political, functional, financial, and technological considerations. However, studies since the beginning of the $21^{\text {st }}$ century have indicated how the absence of a balanced representation of the architectural heritage of the modern era, especially of the colonial period, will leave a gap in knowledge about the evolution of architectural and urban fabrics ${ }^{[1]}$. One negleced topic is the conservation state of religious buildings of the 
indigenous communities in the European colonial territories. In several parts of colonized subSaharan Africa, church and mosque buildings emerged as monumental structures constituting a new layer of urban fabric ${ }^{[2,3,4,5]}$. They are evidence of transcultural knowledge transfer via the introduction of Western design and construction skills and their adaptation to local conditions, however the conservation of these structures has not received much academic attention or governmental priority.

Recent research has indicated how in the absence of heritage management policy and governmental and institutional reluctance to heritagize both Islamic and Christian religious structures has accelerated their deterioration and loss ${ }^{[5,6]}$. This paper is one of the outcomes of a fieldwork-based research project that aims to identify, document and analyze the conservation state of British colonial era built religious heritage in Yorubaland (Figure 1). The fieldwork was conducted over several trips in a period between June 2017 and December 2019. This paper widens the discussion by looking into the existing conservation knowledge separately for mosques and churches, aiming to reveal comparative insights. By employing participant observation and semi-structured interviews with the members of the Building Committees of the surveyed mosque and church structures, it specifically investigates the problems underlying physical modifications on the fabric of buildings and examines the solutions adopted.
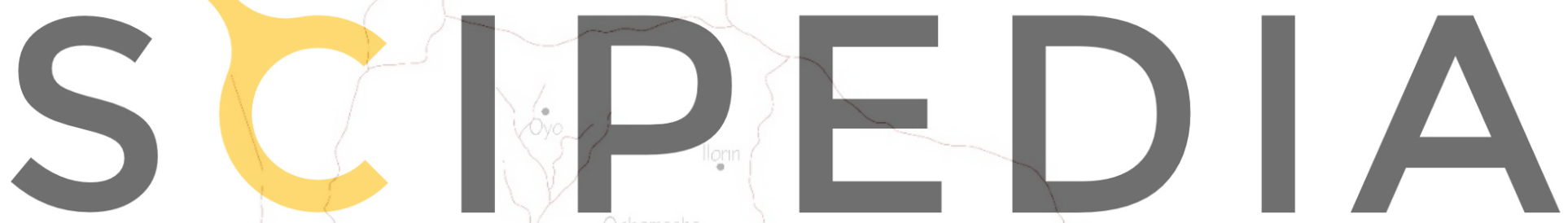

Register for free at https//www.scipedia.com to download the version without the watermark

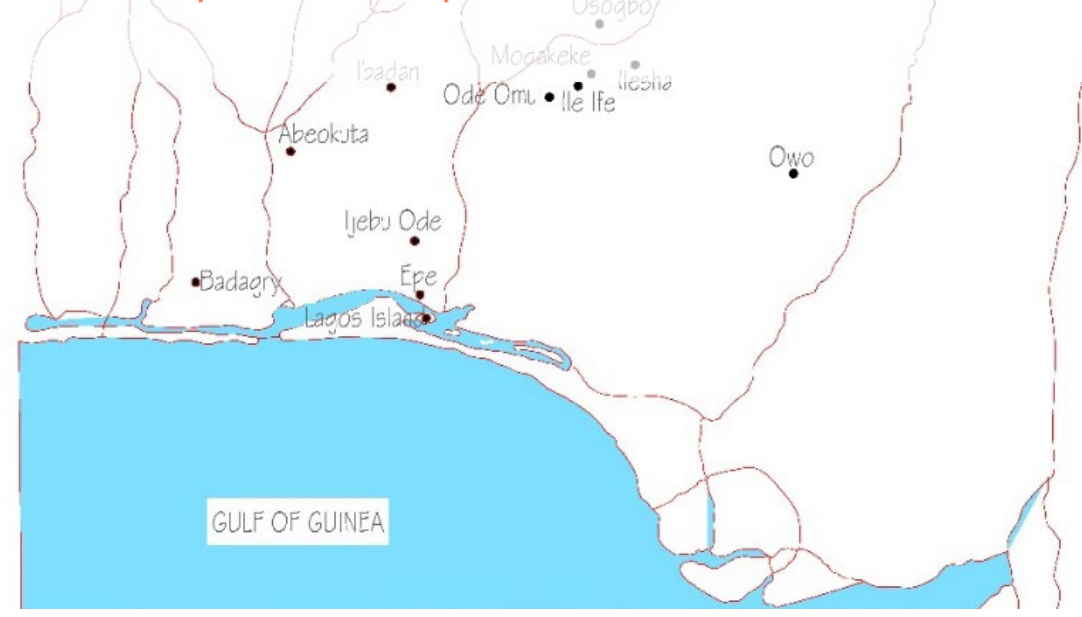

Figure 1: Map of Yorubaland showing the towns/cities surveyed for British colonial-era built religious architecture 


\section{CONTEXTUAL BACKGROUND: IDENTIFICATION OF RELIGIOUS BUILDINGS ERECTED DURING THE BRITISH COLONIAL-ERA IN YORUBALAND}

Islam and Christianity gained a foothold in Yorubaland mainly during the $19^{\text {th }}$ century. Although there had been small numbers of Muslims in Yorubaland since the $17^{\text {th }}$-century, Islam's presence gained momentum after the Fulani Jihan in $1830 \mathrm{~s}{ }^{[7,8]}$. This was followed by Christianity in the early 1840 s, when the abolition of slavery and Britain's intensified presence in West Africa in the heyday of the British Empire introduced led to the introduction of Christian missionaries and instigated a radical change in religious space ${ }^{[9,10]}$. Both Islam and Christianity increasingly became the major religions in Yorubaland replacing by the beginning of the $20^{\text {th }}$ century the hitherto prevailing African traditional religions. By then, unlike the unpretentious religious spaces belonging to African traditional religious sites ${ }^{[11]}$, architectural aesthetics had gained a significant role in designing both the mosques and churches ${ }^{[12,13]}$.

\subsection{Typology and morphology of Afro-Brazilian mosques in colonial Yorubaland}

Until the late- $19^{\text {th }}$-century mosques in Yorubaland were small-scale and unadorned mudand-thatch structures, often without minarets ${ }^{[7,8]}$. Contact with the wider world from the second half of the $19^{\text {th }}$ century led to the building of more impressive mosques in West Africa ${ }^{[4]}$. This coincided with the return of freed Africans who were enslaved in Latin America, especially in Brazil. The design of Afro-Brazilian mosques imitated the $17^{\text {th }}$ to $18^{\text {th }}$-century Baroque

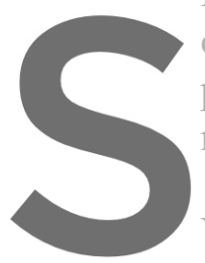
churches in Bahia in Brazil, with a longitudin
pedimented central structure and bell towers
mihrab was installed on the Qibla wall, and the
These Afro-Brazilian style mosques intro
Yorubaland. The earliest ones were erected in
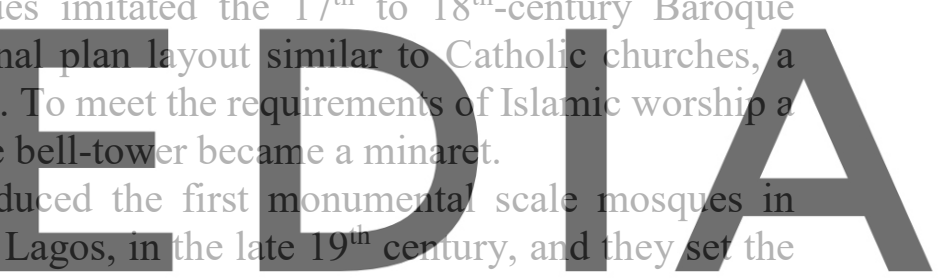

architectural vocabulary for several chief congregational mosques in Yoruba cities, with most

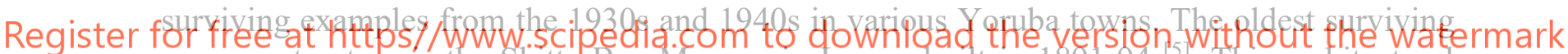
mosque structure is the Shitta Bey Mosque in Lagos, built in $1891-94$. 5 . This architectural

language included a pedimented central structure, with single or double minaret-towers situated on the front or rear façade; in both cases having the similar longitudinal plan layout. The details and ornaments changes drastically depending on the repertoire of the master-builders, including: pediment crowned with scrolls, round or elliptical oculi and arched openings with stucco surrounds, stringcourse that extends horizontally on the façades, engaged columns, pilasters and plinths, and various stucco decorations, emphasized quoins, rectangular windows topped with decorated blind arches or floral motifs, ornate balustrades surmounting the minarettowers and roof lines, and Baroque style dormers on the roof level of the side facades (Figure 2). 


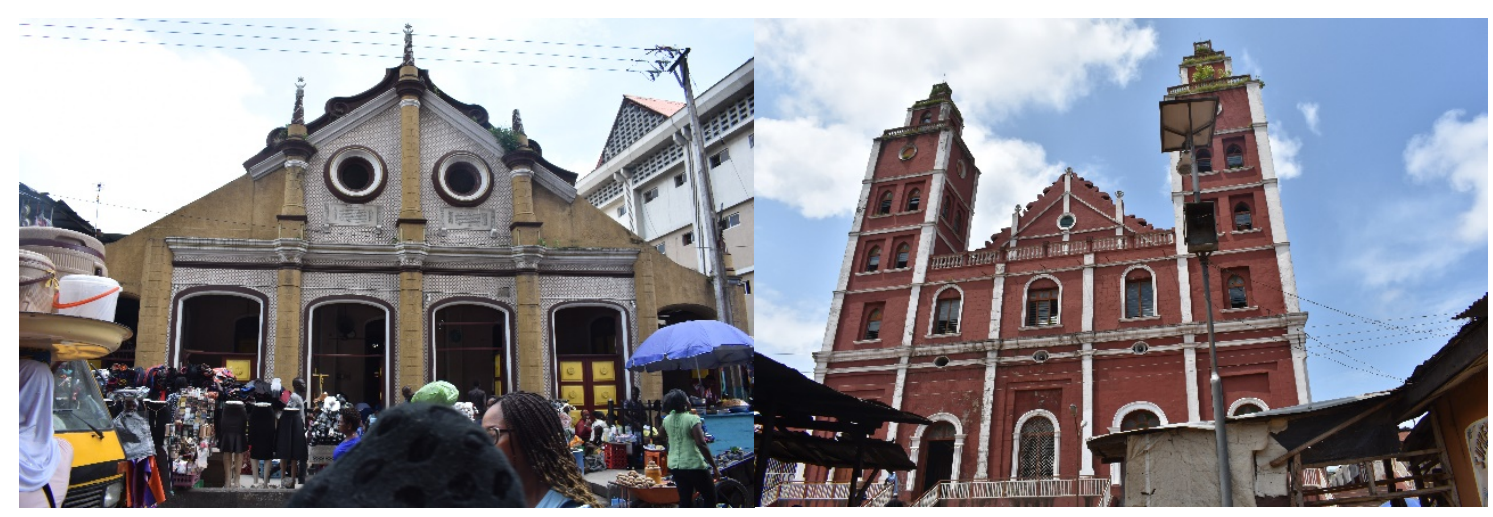

Figure 2: Shitta Bey Mosque in Lagos (left), and Central Mosque in Abeokuta (right)

\subsection{Typology and morphology of missionary churches in colonial Yorubaland}

The emergence of church structures in Yorubaland started with the establishment of the first formal church, St Peter's Church in Ake, Abeokuta in $1847^{[14]}$. While the early churches in Yorubaland were erected under the directives of the missionaries, these were mainly mud-andthatch structures which did not survive. Similarly to mosques, churches with durable materials, mainly brick, stone and metal roofing sheets, started to emerge in the last quarter of the $19^{\text {th }}$ century. The $20^{\text {th }}$ century witnessed the reconstruction of these structures in larger scales to accommodate their growing congregations. The oldest surviving church building is the St. Peter's Church in Ake, built during 1898-1900. While initially the hall-type dominated, from the 1910s until the end of the colonial era, churches were designed mostly in Basilica laycut Neo-Gothic style, both in European versions and in simplified-localised versions, dominated
the morphology and aesthetic of the churches from the late $19^{\text {th }}$ century, including: pointed arches, lancet windows with Gothic style nullions, oculi, archivolts, stringcourses, nave arcades with compound piers supporting pointed arches (Figure 3).

Register for free at https//www.scipedia.com to download the version without the watermark

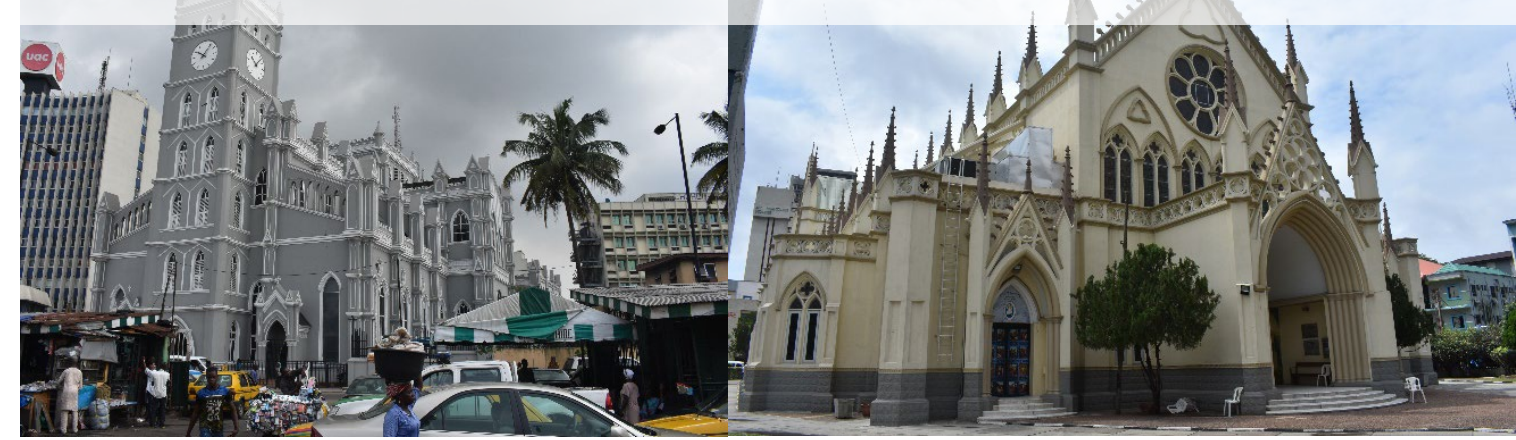

Figure 3: Christ Church Cathedral (left), and Holy Cross Church Cathedral (right) in Lagos

\section{HERITAGE MANAGEMENT, KEY CONSERVATION PROBLEMATICS AND THE STATE OF KNOW-HOW}

Form early on, construction of mosques and churches has been the responsibility of their respective communities, erected and maintained through funds, services and with 
construction/finishing materials endowed by charitable citizens. During our fieldwork, we observed that both churches and mosques are self-sustained autonomous entities, and hence the upkeep and maintenance of religious space is under their leaderships' autonomy. In both institutions, each individual church parish and mosque community establishes their respective Building Committee with persons selected from their members to manage the upkeep and maintenance works. However, semi-structured interviews with members of various committees revealed that while there are architects/ engineers in building committees, they are not experts in architectural conservation. It is too simplistic to argue that their selection is intentionally based solely on their loyalty to the respective institution's administration. There is also the reality that the number of heritage management and conservation experts is rather low in Yorubaland (and in fact in Nigeria) due to the near absence of the discipline both in formal and vocational education.

Another problem is the absence of religious heritage belonging to Islam and Christianity in the national heritage legislation, namely the Decree No: 17 of 1979 (Ordinance of 1979) ${ }^{[6]}$. While there are only three mosque sites listed in the national heritage list, there are no churches included in it yet. This is a situation which lends the leadership of religious buildings a free hand in undertaking decisions regarding physical interventions on the buildings' fabric and sometimes even to make controversial decisions. Exemplifying this is the case of the Central Mosque in Lagos: being one of the earliest Afro-Brazilian style mosques, designed in 1897 as the chief mosque of the country, the Central Mosque in Lagos was inspirational in the design of others around Yorubaland [5]. Following its demolition in 1980, a colossal post-modern structure was built in its place, which was surprisingly (athd ironically) lates declared an ancient
monument in the heritage list of the State of Lagos (Chapter L86), as a 'modern architectural
masterpiece, built to replace the old mosque' ${ }^{[15]}$.
Our extensive fieldwork in Yorubaland has revealed several key reasons underlying physjeal
interventions on the religious structures. These include spatial requirements for groving congregations, material deterioration, structural decay, cosmetic interventions for aesthetic

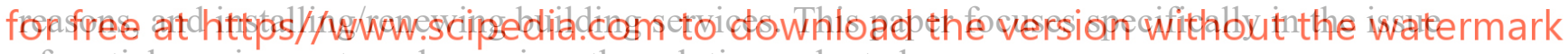
of spatial requirements and examines the solutions adopted.

\section{SPATIAL REQUIREMENTS FOR GROWING CONGREGATIONS AND THE SOLUTIONS ADOPTED}

Both in mosques and churches, increased congregation numbers have prompted attempts to create larger spaces. This is usually achieved in three ways: either by demolishing the old structure to make space for a new one, expanding the old structure, or building a new structure on the site and adapting the old one to a new use.

\subsection{Demolishing the old mosques and churches to make space for new and larger ones}

In several cases, lack of space at the religious site prompts the demolition of the original structure to create space for a new and larger one. This is especially the case in crowded urban areas such as Lagos, where plot sizes are relatively small. Sadly, several early mosques and churches such as the old Central Mosque, the First Baptist Church, and the Ebenezer Church in Lagos have been demolished for this reason. Colossal post-modern structures now occupy the sites. 


\subsection{Expansion of the old mosque and church structures by the addition of new spaces}

The expansion of the old structure by adding to one or both sides is among the most popular solutions both for mosques and churches. In some cases, such as the Central Mosque in Abeokuta or Christ Church in Ijebu-Ode, the expansión remains in harmony with the existing part both morphologically and in terms of its size. There are several cases however where massive expansions have been built, such as the extension of the southerly façade of the OdeOmu Central Mosque adding two slender minarets, with an external gallery around the old and new mosque. This extensión from c.1980s, destroyed the original facades, and little of the front pediment, flanking the minaret-tower and some of the rear pediment, has survived (Figure 4). On the other hand, the expansion of the Central Mosque in Offa, where it has been extended on its lateral sides, tripling the total closed área, was more thoughfully carried out. With large domes on top, surmounted by crenellated parapets with slender minarets, and two new polygonal towers on the main façade of the original building, provide an eclectic example of Middle-Eastern mosque architecture. The original building is now constricted by the expansion, started in c.1980s and eventually finished in c.2010 (Figure 4). In another case, at the Central Mosque in Ijebu Ode, an extension in the style of the old facade has been continuing since c.1990s, making it hard to tell the old and new elements apart. Two hemispherical domes were built in front of the pedimented gable, obliterating it (Figure 4).
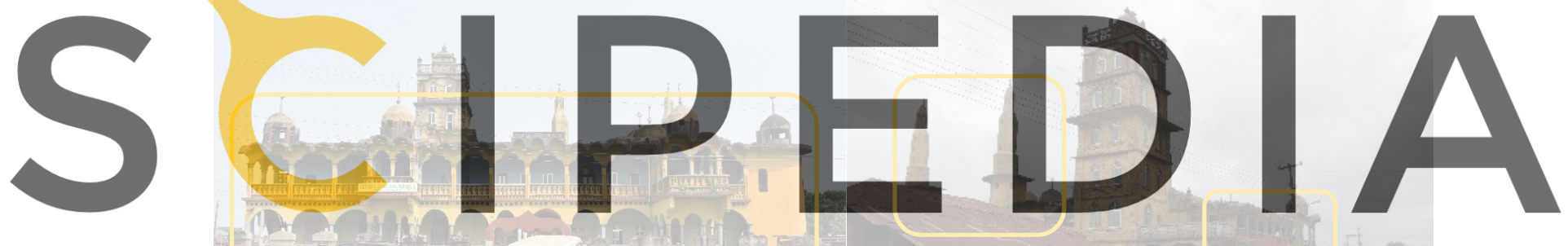

Register for free at https//www.scipedia.com to download the version without the watermark

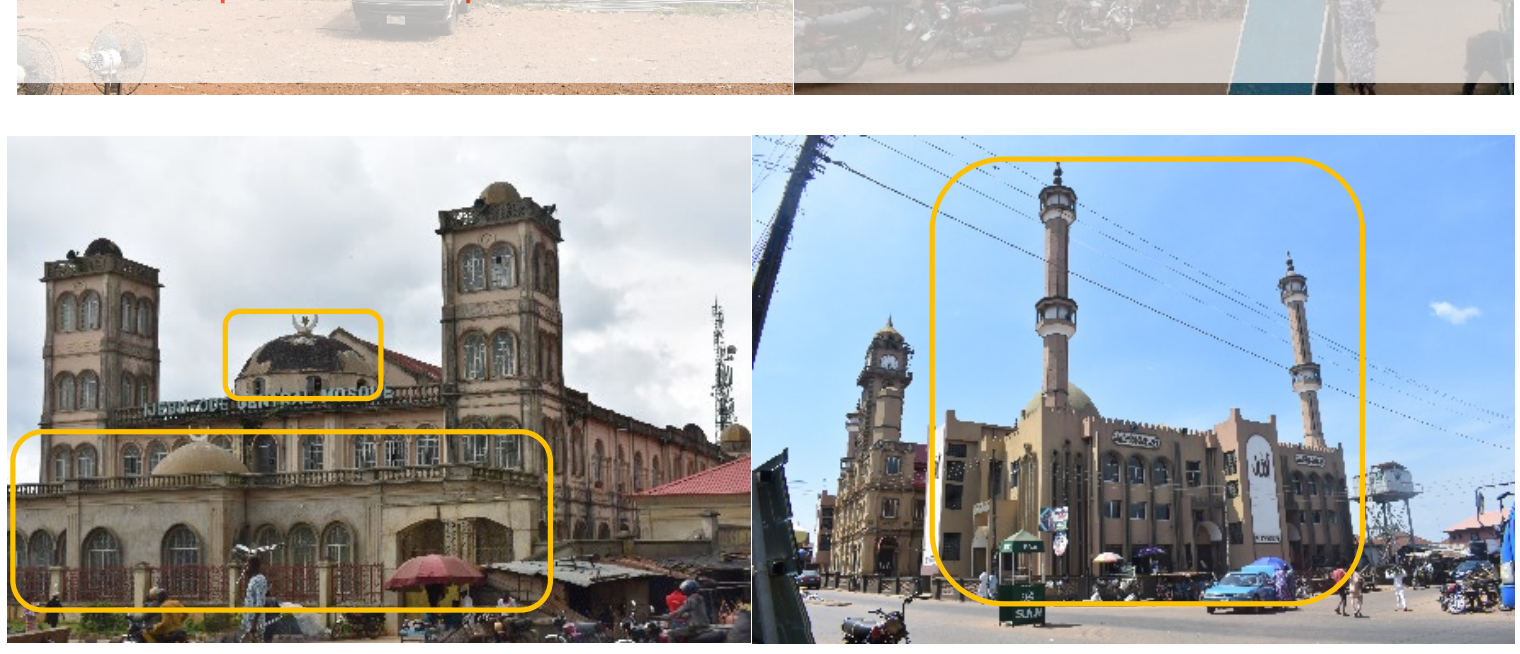

Figure 4: Expansions on Central Mosque in Ode-Omu (above), Ijebu Ode (below, left), and Offa (below, right). 
Among the most radical modifications are the addition of towers in addition to congregation and administrative spaces. For the mosques, a case in point is the Central Mosque of Osogbo, where two new minaret-towers were added to the existing tower and single hall layout mosque in ongoing extension work started c.1995. The new square minaret-towers are similar to the original tower (Figure 5). However, a massive dome was installed as an afterthought to the expanded section which does not suit the building. The facades of the original mosque have been obliterated as the building was expanded. Overall, the expansion is too massive and the morphology of the new additions cause confusion rather than harmonious integration. In a similar vein, a new hall and a bell-tower was added to the originally two-bell-towered Holy Trinity Church in Abeokuta, replicating the existing ones, and making it difficult to differentiate the newly added parts from the originally existing ones (Figure 5).

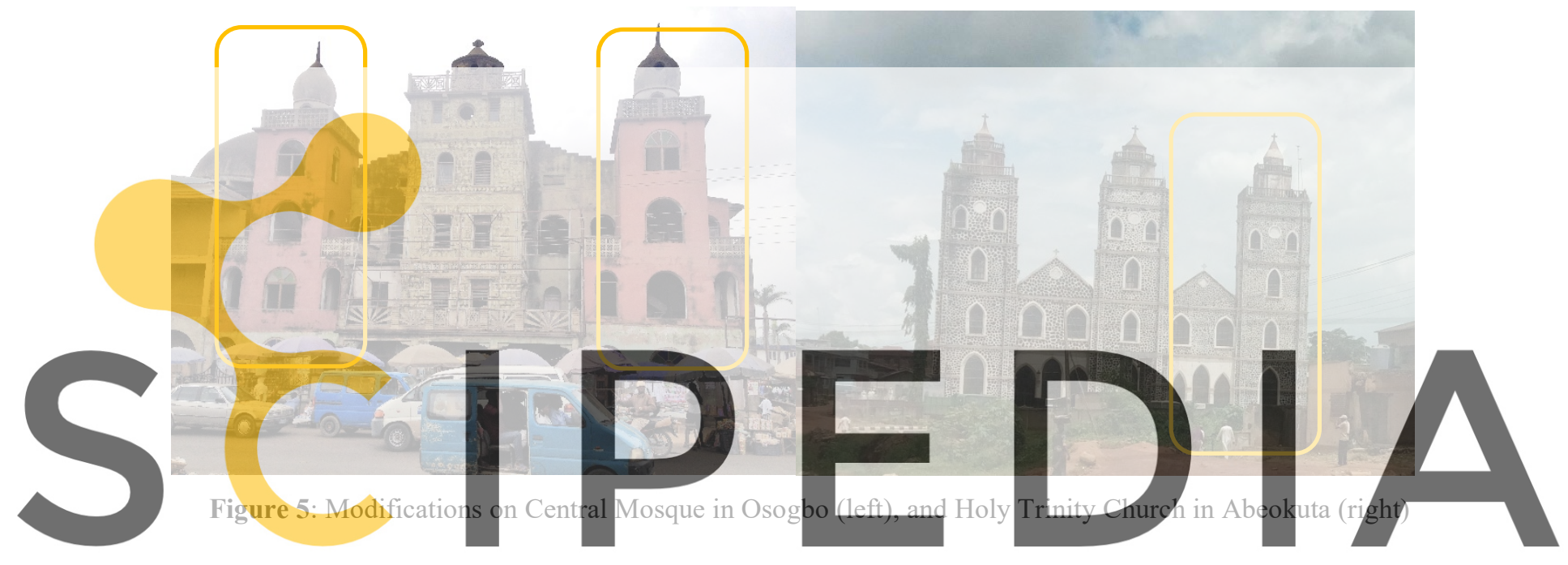

4.3 Constructing a mew structure and adapting the old one for new purposes

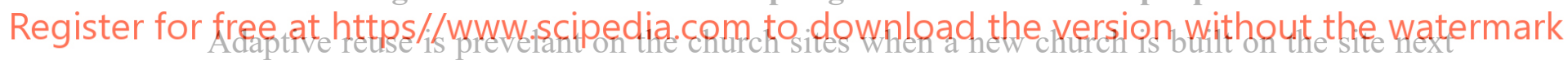

to the old one. There is rarely any attempt to create a harmony of architectural languages between the old and new. Exemplifying adaptive reuse are the St Peter's Church in Abeokuta, St. James's Church in Ibadan, Aatan Baptist Church in Oyo, Our Saviour's Church in Ijebu Ode and St. Philip's Church in Ile Ife. While the last one has remained unused since 2014, awaiting final decisións about its future use, in all other cases the old building has been adapted to be for church related functions. Note that, in all cases, the old buildings show signs of material deterioration and structural decay due to the lack of upkeep and maintenance.

In a different approach, when more space was needed for congregations at the Our Saviour's Church in Lagos and a new structure was built surrounding the old one, the latter remained in use in its original function (as a suplementary church space). However, while the facades of the new structures replicate the windows of those at the old church, creating a somehow succesful harmony, the scale of the new structures are massive, dwarfing the old building (Figure 6). 


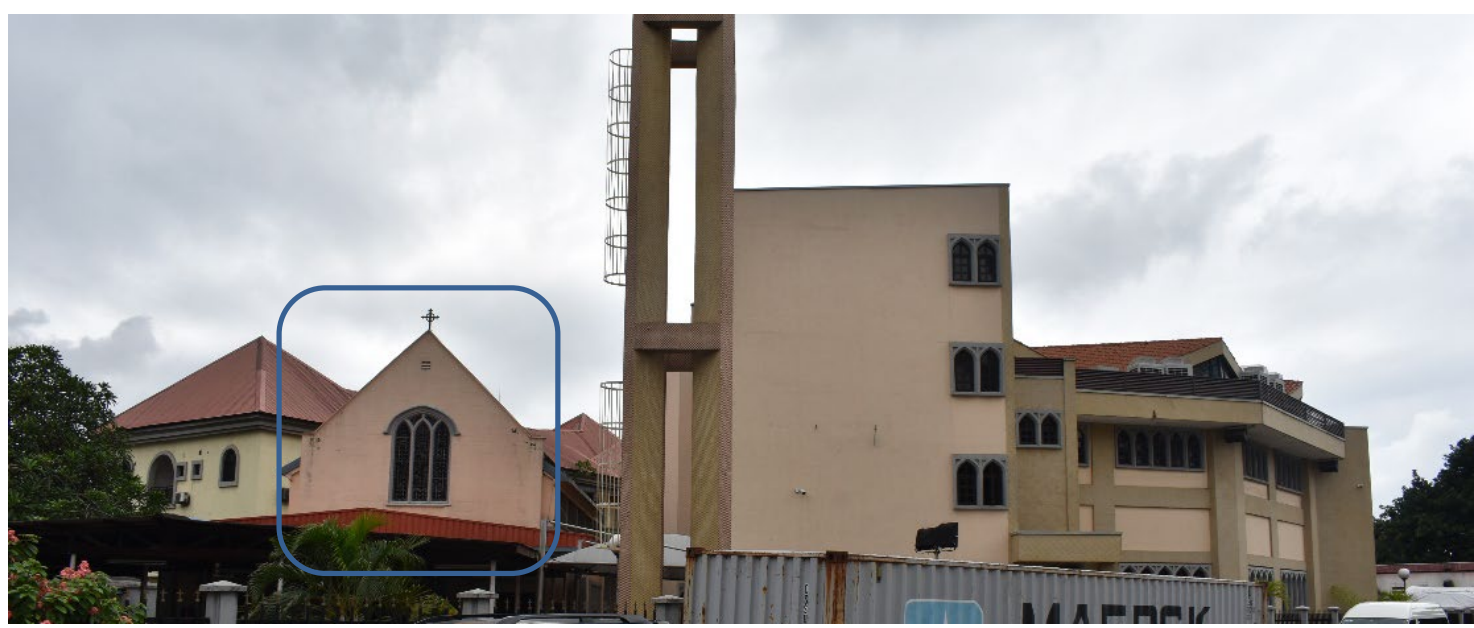

Figure 6: Our Savious' Church (Lagos), cramped in recently constructed new church buildings

\section{DISCUSSION AND CONCLUSION}

Colonial-era religious built heritage in Yorubaland, which includes Afro-Brazilian mosques and missionary churches, are significant layers of urban fabric. They bear witness to an era of transculturation, during when the Western construction technology and design understandings were imported to the región in part by the Western community and in part by the Africans from the urban fabrics.

This paper has shec light on hoy spatial requirements in buildings' fabric. Both in the case of Afro-Brazilian mosq common key problem is that these buildin requirements for providing larger space for
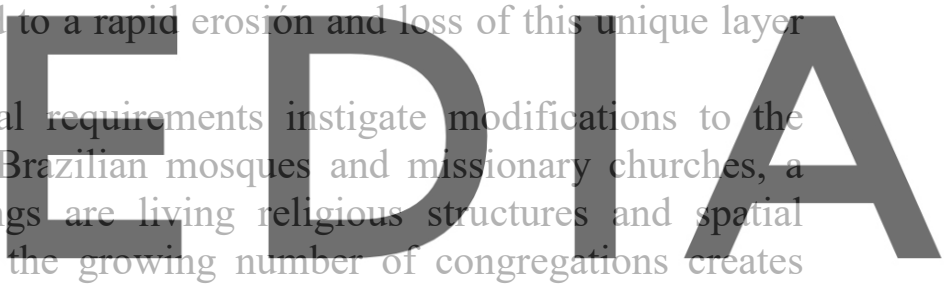
pressure for irreversible extensive modifications on the religious structures' fabric. In the denser

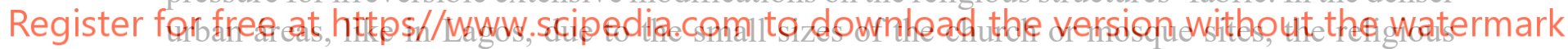

communities favor demolition or massive expansions. In the cases when the old building is

kept, the new structures often do not integrate respectfully with it. Either they dwarf it or create confusing volumetric expressions. On the other hand, in less populated urban areas the availability of space on the site allows for new constructions, opening the way for adaptive reuse for the old church or mosque structure, although these are seldom protected as heritage structures. In any case, whether the structure is used in its original function or it is adapted for reuse, the material and structural problems are addressed as normal construction works.

The current lack of institutional heritage management policy and conservation expertise, coupled with the implicit absence of religious buildings belonging to Islam and Christianity from the national preservationist legislation, suggests what may lay ahead for these heritage structures. Protection of the remaining examples depends on actions that need to be taken at governmental, institutional, and inter-institutional levels. While the de-centralized and community-based management system of both the church and the mosque institutions is a strength to build on, it is obvious that these systems need to be embedded with heritage capacity/mechanism and monitored from the top (the local and federal government). The best way forward should start with identifying, locating, and listing the remaining colonial-era 
religious buildings and tailoring a heritage management policy to protect them while also ensuring their continuing use as religious sites under the control of their respective religious communities.

\section{REFERENCES}

[1] van Roosmalen, P. Changing Views on Colonial Heritage. In: R. van Oers and S. Haraguchi (Eds.): Identification and Documentation of Modern Heritage, World Heritage Papers no 5, UNESCO (2003), pp.122-129.

[2] Bremner, G. A. Imperial Gothic: Religious Architecture and High Anglican Culture in the British Empire. Yale University Press (2013).

[3] Hallen, B. Afro-Brazilian Mosques. Mimar: Architecture in Development (1988) 29:16-23.

[4] Cantone C. Making and Remaking Mosques in Senegal. Brill (2012).

[5] Sabri, R. and Olagoke, O.A. Rethinking the Conservation of Afro-Brazilian Mosque Legacy. Journal of Architectural Conservation (2019) 25 (1-2): 49-71.

[6] Sabri, R. and Olagoke, O. A. Predicaments in the Management of Religious Heritage Buildings and Sites in Nigeria. Conservation and Management of Archaeological Sites (2019) 21(1): 45-65.

[7] Jawondo, I.A. Architectural History of Ilorin Mosques in the Nineteenth and Twentieth Centuries. Social Dynamics (2012) 38(2): 303-312.

[8] Dmochowski, Z. R. An Introduction to Nigerian Traditional Architecture: Northern Nigeria. Ethnograph

[9] Osifodunitin, P. The 1852-2016. Ibadan

[10] Ogundipe, S. A. (Anglican Communio
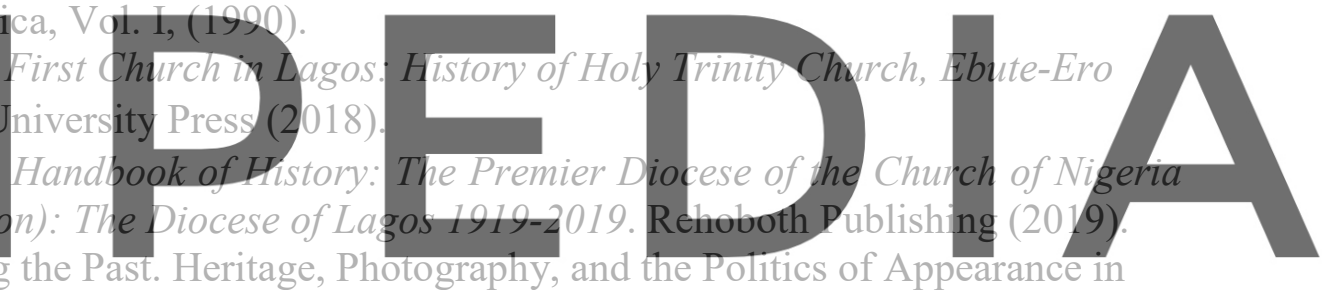
a Yoruba Town. In: M. Rowlands \& F. de Jong (Eds.) Reclaiming Heritage. Alternative

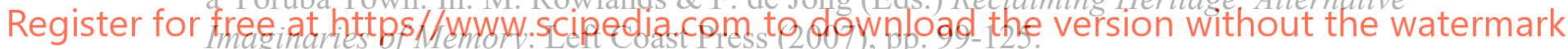

[12] J. Picton. Keeping the Faith: Islam and West African Art History in the Nineteenth Century. In: D. Behrens-Abouseif and S. Vernoit (Eds.) Islamic Art in the $19^{\text {th }}$ Century. Koninklijke Brill NV (2006), pp. 191-230.

[13] A. Vaughan-Richards. Le Nigeria. In: J. Soulillou (Ed.) Rives Coloniales. Architectures, de Saint-Louis À Douala. Editions de l'OR5TOM (1993), pp. 245-88.

[14] The Cathedral Standing Committee. The Cathedral of St. Peter, Ake, and Christianity in Nigeria: Chronicle of History 1843-2013. Oba Oyebade Lipede Christian Books Centre, Abeokuta (2013).

[15] Chapter L86: A law to provide for the preservation, protection and restoration of historical properties and cultural heritage sites in Lagos state and for connected purposes. Listed Sites (Preservation) Law. Lagos State of Assembly, 27 June 2011. 